\title{
New Protocol for Colchicine Induced Efficient Doubled Haploidy in Haploid Regenerants of Tetraploid and Hexaploid Wheats at In vitro Level
}

\author{
P. Sharma*, H.K. Chaudhary, N.V. Manoj and P. Kumar \\ Molecular Cytogenetics and Tissue Culture Laboratory, Department of Crop Improvement, \\ CSK HP Agricultural University, Palampur-176062, Himachal Pradesh, India
}

(Received 5 November 2018; Accepted 12 February 2019)

\begin{abstract}
An investigation to standardize the protocol for in vitro application of colchicine for enhancing the doubled haploid production in wheat was done. Two tetraploid (PDW-314 and A-9-30-1); and two hexaploid (DH-40 and C-306) wheat genotypes were used as maternal parents, whereas, the pollen sources involved Zea mays (cv. Bajaura Makka) and Imperata cylindrica. During the rabi seasons of years 2013-14 and 2014-15, wheat $\times$ maize and wheat $\times$ I. cylindrica hybridization was carried out followed by treatment of their haploids produced as a result of elimination of chromosomes of maize and I. cylindrica respectively, with varied doses of colchicine for different durations The various doses of colchicine were categorized into two groups: lower doses for longer durations $(0.01,0.025,0.05 \%$ each for $5,7,9,11 \mathrm{hrs})$ and higher doses for shorter durations $(0.05,0.075,0.10,0.15,0.20$, $0.25 \%$ each for $5,4,3,2 \mathrm{hrs}$ ). The response of different concentrations of colchicine applied for varied durations revealed significant differences for various doubled haploidy parameters viz., per cent survived plants, per cent doubled haploid formation and per cent doubled haploid seed formation. In hexaploid and tetraploid wheats, colchicine doses of $0.075 \%$ for $4 \mathrm{hrs}$ and $0.15 \%$ for $4 \mathrm{hrs}$, respectively were established as optimum for enhanced doubled haploid production.
\end{abstract}

Keywords: wheat $\times$ Imperata cylindrica, chromosome elimination, colchicine, in vitro, doubled haploids

\section{Introduction}

Doubled haploidy breeding with complete homozygosity in different crop species is the best alternative to conventional breeding approaches in respect of time, cost and population size required to produce pure lines (Garcia-llamas et al. 2004). This breeding method may reduce the time to attain complete homozygosity and helps in the quick development of complete homogeneous and homozygous lines as compared to conventional approaches that may take up to 14 years to develop a single wheat cultivar (Baenziger et al. 2001). Additionally, this approach helps in easy identification of deleterious mutations which are usually in recessive state and remains unidentified in other approaches but in case of haploids that express in hemizygous state, plants can express both dominant and recessive

\footnotetext{
*Corresponding author; E-mail: sharma.paru1023@gmail.com
} 
mutations. Doubled haploidy technology plays an important role in developing transgenics with the desired traits (Patnaik and Khurana 2001; Foster et al. 2010; Chauhan and Khurana 2011).

During the last few years, chromosome elimination approach has proved to be the efficient system of doubled haploidy breeding as compared to other biotechnological tools like androgenesis mediated approach (Chu et al. 1973; Ouyang et al. 1973; Wang et al. 1973). Chromosome elimination-mediated doubled haploidy breeding includes the various approaches viz., bulbosum technique (Barclay 1975), wheat $\times$ maize system (Laurie and Bennett 1987, 1988) and the recently discovered wheat $\times$ Imperata cylindrica system which has emerged as the best choice for haploid induction in wheat (Chaudhary et al. 2005, 2013a, 2013b; Chaudhary 2008, 2009, 2010a, 2010b; Kaila et al. 2012) as well as in durum wheat (Mahato and Chaudhary 2015). Despite immense importance and advantages of doubled haploidy (DH) breeding, its extensive adoption in crop improvement programmes is lacking because of low frequency of production of doubled haploids due to high mortality rate of regenerated haploid plants after colchicine treatment. This limitation necessitates and demands standardization of an appropriate dose and duration of colchicine application.

Colchicine application is a key step in the DH breeding programme for inducing chromosome doubling in haploid plantlets, which affects the frequency of DH production to a great extent. Although workers across the world have made concerted efforts for in vitro application of colchicine to get desirable number of DHs, yet more focused approach is required to determine the dose of colchicine and the appropriate time interval for its application after haploid regeneration so as to draw concrete inferences. No such endeavor has been done in the I. cylindrica-mediated chromosome elimination approach of doubled haploidy breeding in hexaploid and tetraploid wheats for efficient recovery of doubled haploids. Keeping in view the impact of this hurdle, various modifications/manipulations in colchicine doses and durations were executed in the present investigation, which provided an opportunity to eliminate the constraint of lethality to some extent and enhance the efficiency of DHs production.

\section{Materials and Methods}

Two wheat genotypes namely, DH-40 and C-306 representing spring wheat (Table S1*) and two durum wheat genotypes viz., A-9-30-1 and PDW-314 (Table S2) were utilized as female parents in hybridization programme whereas a composite variety of maize-Bajaura Makka and I. cylindrica, a wild weedy perennial grass were taken as male parents. Five staggered sowings of parental material were done to coincide the flowering times of wheat genotypes with maize and I. cylindrica. Ample number of spikes from each wheat genotype were pollinated with each pollen source i.e. Bajaura Makka and I. cylindrica following haploid induction protocol of Laurie and Bennett (1986 and 1988) and Chaudhary et al. (2002 and 2005) at the Experimental Farm of the Department of Crop Improve-

*Further details about the Electronic Supplementary Material (ESM) can be found at the end of the article. 
ment, CSK HPKV, Palampur, Himachal Pradesh during rabi 2013-2014 and 2014-2015 to obtain sufficient number of haploids.

A solution of $100 \mathrm{ppm} 2$, 4-D in bread wheat and $250 \mathrm{ppm}$ in durum wheat was injected in the uppermost internode of the wheat culms for three consecutive days at $24 \mathrm{hrs}$, $48 \mathrm{hrs}$ and $72 \mathrm{hrs}$ after pollination. The injection holes were sealed by using petroleum jelly. After 18-20 days of pollination, the crossed spikes were harvested from the tiller base. The embryo carrying seeds were identified under a source of light (Bains et al. 1998). The embryo was seen floating in the liquid endosperm as against the solid endosperm found in selfed seeds. The embryo carrying pseudoseeds were washed thoroughly using Tween-20 under tap water to avoid any sort of contamination/infection. At the time of embryo rescue in Laminar Air Flow Chamber, surface sterilization of pseudoseeds was done using 0.1 per cent $\mathrm{HgCl}_{2}$ and 0.1 per cent bavistin each for 1-2 minutes followed by two washing with autoclaved distilled water. The embryos were then excised from sterilized pseudoseeds and transferred to the test tubes containing Murashige and Skoog (1962) medium supplemented with essential amino acids. The cultured tubes were shifted to $4{ }^{\circ} \mathrm{C}$ temperature to fulfill the need of cold treatment in dark for first 24 hours. Then for about 7-8 days up to the initiation of roots and shoots from cultured embryos they were incubated in the Plant Growth Chamber at $20 \pm 2{ }^{\circ} \mathrm{C}$ in the dark. After regeneration, the tubes were transferred to the other division of the Chamber maintained at $20 \pm 2{ }^{\circ} \mathrm{C}$ with $10 / 14 \mathrm{hrs}$ light/dark profile and 75 per cent relative humidity for further growth of plantlets. Potting mixture was prepared by mixing coco peat, vermiculite and perlite in the proportion of $3: 1: 1 \mathrm{v} / \mathrm{v}$. The plantlets were then shifted to the soil less media in small pots $(5 \mathrm{~cm}$ diameter) for proper rooting and shooting. Appropriate conditions viz., $20 \pm 2{ }^{\circ} \mathrm{C}$ with $10 / 14 \mathrm{hrs}$ light/dark profile and 75 per cent relative humidity were maintained for proper growth until maturity. After attaining 2-3 leaf stage haploid plantlets were subjected to colchicine for the doubling of chromosomes.

In the experiment of in vitro colchicine application, the haploid plantlets produced were treated with the different doses of colchicine for varied durations. The experiment was categorized into two groups: (a) Application of higher dose of colchicine for shorter duration, i.e. $0.05,0.075,0.10,0.15,0.20$ and $0.25 \%$ each for $5,4,3,2$ hrs (Table S3a) (b) Application of lower dose of colchicine for longer duration, i.e. 0.01, 0.025, 0.05\% each for 5, 7, 9, $11 \mathrm{hrs}$ (Table S3b). Considering $0.05 \%$ colchicine dose for $5 \mathrm{hrs}$ to be the standard, doses above $0.05 \%$ were taken as higher doses for the shorter durations i.e. below $5 \mathrm{hrs}$ and below $0.05 \%$ were taken as lower doses for the longer durations i.e. above 5 hrs. For each treatment, three haploid plantlets were used as replications. Each dose of colchicine was supplemented with $1.5 \%$ dimethyl sulfoxide (DMSO) that act as osmoregulator. The roots of plantlets were trimmed and at about $20^{\circ} \mathrm{C}$, those plantlets were dipped into the colchicine solution. During the treatment, roots along with crown part should be dipped into the solution. After the treatment with various doses of colchicine for different durations at $20^{\circ} \mathrm{C}$, the plants were removed from colchicine solution, rinsed in running tap water for $1 \mathrm{hr}$ and planted into pots with potting mixture i.e. soil less media and kept in proper growth condition with $10 \mathrm{hrs}$ day length regime at 75 per cent relative humidity and $20 \pm 2{ }^{\circ} \mathrm{C}$ temperature till the proper development of plantlets. After 
proper growth, the treated plants were transferred to potting mixture, prepared by mixing soil, sand and vermicompost in the definite proportion of $2: 1: 1 \mathrm{v} / \mathrm{v}$ and then kept in the greenhouse. Appropriate conditions viz., $20 \pm 2{ }^{\circ} \mathrm{C}$ with $10 / 14 \mathrm{hrs}$ light/dark profile and 75 per cent relative humidity were maintained in the greenhouse for proper growth. Later the plants were transferred to natural conditions in experimental fields during rabi season of 2014-2015 for further observation of seed setting, if any. The whole experiment was repeated for the next following rabi season of 2014-2015 and the effective dose of colchicine and its duration was decided based on seed setting observed in the plants shifted to the field during rabi seasons of 2014-2015 and 2015-2016.

Data pertaining to per cent survived plants (total number of plants survived after colchicine treatment/total number of plants used for colchicine treatment), per cent DH formation (number of survived plants carrying seeds/total number of plants survived after colchicine treatment), per cent seed formation (total number of seeds in fertile plants/ total number of florets in fertile spikes) were recorded in tetraploid and hexaploid wheats except for hexaploid wheat, $\mathrm{DH}-40$, due to the poor performance of genotype with respect to various haploid induction parameters that resulted in non-availability of haploid plants. To test the significance of different concentration of colchicine in the hexaploid and tetraploid wheat genotypes, simple $t$-test was performed.

\section{Results}

\section{Effect of higher doses of colchicine for shorter durations}

\section{Per cent survived plants}

During the first year 2013-2014, in hexaploid wheat, C-306, the results analyzed following student's $t$-test indicated that although plants survived with all the concentrations except $0.05 \%$ for $4 \mathrm{hrs}$ and $3 \mathrm{hrs}, 0.10 \%$ for $4 \mathrm{hrs}, 0.15 \%$ for $2 \mathrm{hrs}$ and $0.20 \%$ for $2 \mathrm{hrs}$, the survival rate was found to be significantly positive only for concentrations of $0.075 \%$ for $2 \mathrm{hrs}, 0.20 \%$ for $5 \mathrm{hrs}$ and $0.25 \%$ for $4 \mathrm{hrs}$ (Table 1 ). The data was analyzed for each dose of colchicine over all the durations i.e. over the time period to determine which duration is effective among all the durations for a particular colchicine dose. In durum wheat, PDW-314, colchicine concentration of $0.05 \%$ for $5 \mathrm{hrs}, 0.075 \%$ for $4 \mathrm{hrs}$ and $0.25 \%$ for $5 \mathrm{hrs}$ and in A-9-30-1, $0.15 \%$ for $4 \mathrm{hrs}$ and $0.20 \%$ for $2 \mathrm{hrs}$ exhibited significantly positive effect over the time period on per cent survived plants (Table 1).

In the 2nd year of experiment, in C-306, the survival rate was found to be significantly positive for concentration of $0.05 \%$ for $2 \mathrm{hrs}, 0.075 \%$ for $2 \mathrm{hrs}$ and $0.20 \%$ for $5 \mathrm{hrs}$ over the time period (Table 2). In durum wheat, PDW-314, colchicine concentration of $0.075 \%$ for 4 and $3 \mathrm{hrs}, 0.15 \%$ for $3 \mathrm{hrs}, 0.20 \%$ for $5 \mathrm{hrs}$ and $0.25 \%$ for $5 \mathrm{hrs}$ and in A-9-30-1, $0.05 \%$ for $4 \mathrm{hrs}, 0.75 \%$ for $5 \mathrm{hrs}$ and $3 \mathrm{hrs}, 0.15 \%$ for 5 and $4 \mathrm{hrs}, 0.20 \%$ for $3 \mathrm{hrs}$ and $0.25 \%$ for $5 \mathrm{hrs}$ exhibited significant positive effect over the time period on per cent survived plants (Table 2). 
With respect to the response of genotype, PDW-314 was found to be better in the per cent survived plants as compared to A-9-30-1 that was sensitive to the application of colchicine as mortality was observed at maximum concentration.

\section{Per cent doubled haploid (DH) formation}

During rabi season of 2013-14, in hexaploid bread wheat, C-306, the colchicine concentration of $0.075 \%$ for $4 \mathrm{hrs}$ and $2 \mathrm{hrs}, 0.20 \%$ for $5 \mathrm{hrs}$ and $0.25 \%$ for $3 \mathrm{hrs}$ exhibited significant positive effect over the time period on per cent doubled haploid formation as per the results analyzed following student's $t$-test (Table 1). In tetraploid wheat, PDW-314, the colchicine concentration of $0.075 \%$ for $2 \mathrm{hrs}, 0.15 \%$ for $4 \mathrm{hrs}$ and $0.20 \%$ for $3 \mathrm{hrs}$ and in A-9-30-1, $0.15 \%$ for $4 \mathrm{hrs}$ and $0.20 \%$ for $2 \mathrm{hrs}$ revealed significant positive effect over the time period on per cent doubled haploid formation (Table 1).

In the second year of experiment, the colchicine concentration of $0.075 \%$ for $3 \mathrm{hrs}$, $0.10 \%$ for $4 \mathrm{hrs}, 0.15 \%$ for $5 \mathrm{hrs}, 0.20 \%$ for 4 and $5 \mathrm{hrs}$ and $0.25 \%$ for $3 \mathrm{hrs}$ was found to be significantly positive over the time on per cent doubled haploid formation in C-306 (Table 2). In PDW-314, concentration of $0.075 \%$ for $3 \mathrm{hrs}, 0.15 \%$ for 4 and $5 \mathrm{hrs},{ }^{\prime} 0.20 \%$ for 2 and $3 \mathrm{hrs}$ and in A-9-30-1, $0.15 \%$ for $4 \mathrm{hrs}, 0.25 \%$ for $5 \mathrm{hrs}, 0.20 \%$ for $3 \mathrm{hrs}$ exhibited significant positive effect over the time period on per cent doubled haploid formation (Table 2).

\section{Per cent doubled haploid (DH) seed formation}

In the first year of experiment, the analysis of data following student's t-test in C-306 revealed that colchicine concentration of $0.075 \%$ for $4 \mathrm{hrs}, 3 \mathrm{hrs}$ and $2 \mathrm{hrs}$ and $0.20 \%$ for $5 \mathrm{hrs}$ exhibited significant positive effect on per cent doubled haploid seed formation (Table 1). In PDW-314, analysis of data following student's $t$-test indicated that colchicine concentration of $0.075 \%$ for $2 \mathrm{hrs}$ and $0.15 \%$ for $4 \mathrm{hrs}$ and $3 \mathrm{hrs}$ and in A-9-30-1, $0.15 \%$ for $4 \mathrm{hrs}$ and $0.20 \%$ for $2 \mathrm{hrs}$ revealed significant positive effect over the time period on per cent doubled haploid seed formation (Table 1).

In the second year of experiment, in C-306, colchicine concentration of $0.075 \%$ for 3 and $4 \mathrm{hrs}, 0.15 \%$ for $5 \mathrm{hrs}, 0.20 \%$ for $5 \mathrm{hrs}$ and $0.25 \%$ for $3 \mathrm{hrs}$ was found to be significantly positive over the time period on per cent doubled haploid seed formation (Table 2). In PDW-314, $0.075 \%$ for $4 \mathrm{hrs}, 0.15 \%$ for 4 and $5 \mathrm{hrs}, 0.20 \%$ for 2 and $3 \mathrm{hrs}$ and in A-9$30-1,0.15 \%$ for $4 \mathrm{hrs}, 0.25 \%$ for $5 \mathrm{hrs}$ and $0.20 \%$ for $3 \mathrm{hrs}$ exhibited significant positive effect over the time period on per cent doubled haploid seed formation (Table 2).

\section{Effect of lower doses of colchicine for longer durations}

\section{Per cent survived plants}

In C-306 and PDW-314, the analysis of data following student's $t$-test revealed that during rabi season of 2013-2014, no colchicine concentration was significantly positive 
over the time on per cent survived plants (Table S4). No plant survived in A-9-30-1 indicating the ineffectiveness of lower doses of colchicine for doubled haploid formation in A-9-30-1 (Table S4).

Similar results were found in both bread and durum wheat during rabi 2014-2015 (Table S4).

\section{Per cent doubled haploid (DH) formation}

In the first year of experiment, the analysis of data following the student's $t$-test in C-306 indicated that no concentration of colchicine showed a significant positive effect on per cent doubled haploid formation (Table S4). In durum wheat, i.e. PDW-314, no doubled haploid formation was found indicating the inefficiency of lower doses of colchicine and in A-9-30-1, as no plant was survived, no DH was formed (Table S4).

In the second year of experiment, no doubled haploid was formed in both bread and durum wheat (Table S4).

\section{Per cent doubled haploid (DH) seed formation}

In 2013-2014, the effect of colchicine on per cent doubled haploid seed formation in C-306 was analyzed following the student's $t$-test and it was observed that no concentration of colchicine exhibited a significant positive effect (Table S4). For durum wheat, no doubled haploid seed was formed (Table S4).

During the second year of experiment, no seeds were obtained as no doubled haploid was formed in both bread and durum wheat (Table S4).

\section{Identification of ideal dose and time for in vitro application of colchicine}

The ideal dose and time of application of colchicine was determined on the basis of seed setting in the survived plants, mortality and number of doubled haploid seeds formed in the plants after the colchicine application during rabi seasons of 2013-2014 and 20142015. The results of seed setting indicated that in hexaploid wheat, during both the years of experiment, colchicine concentration of $0.075 \%$ for $4 \mathrm{hrs}$ followed by $0.15 \%$ for $4 \mathrm{hrs}$ and $0.20 \%$ for $5 \mathrm{hrs}$ were the most effective for doubling of the chromosomes (Tables 1 and 2). In tetraploid wheat (PDW-314) colchicine concentration of $0.15 \%$ for $4 \mathrm{hrs}$ followed by $0.075 \%$ for $2 \mathrm{hrs}$ and $0.20 \%$ for $3 \mathrm{hrs}$ were found to be most effective during the first year of experiment as compared to other doses (Table 1). In the year 2014-2015, colchicine concentration of $0.20 \%$ for 2 hrs followed by $15 \%$ for $4 \mathrm{hrs}$ and $0.075 \%$ for $4 \mathrm{hrs}$ were found to be the most effective (Table 2). Due to high mortality rate at concentration $0.20 \%$ (Table 2), $0.15 \%$ for $4 \mathrm{hrs}$ can be recommended as ideal dose in PDW-314. In A-9-30-1, colchicine concentration of $0.20 \%$ for $2 \mathrm{hrs}$ was found to be the most effective followed by $0.15 \%$ for 4 hrs during both the years of experiment (Tables 1 and 2). The colchicine concentration of $0.15 \%$ for $4 \mathrm{hrs}$ can be recommended as ideal dose in A-9-30-1 due to mortality rate at concentration $0.20 \%$ (Tables 1 and 2). Therefore, this 


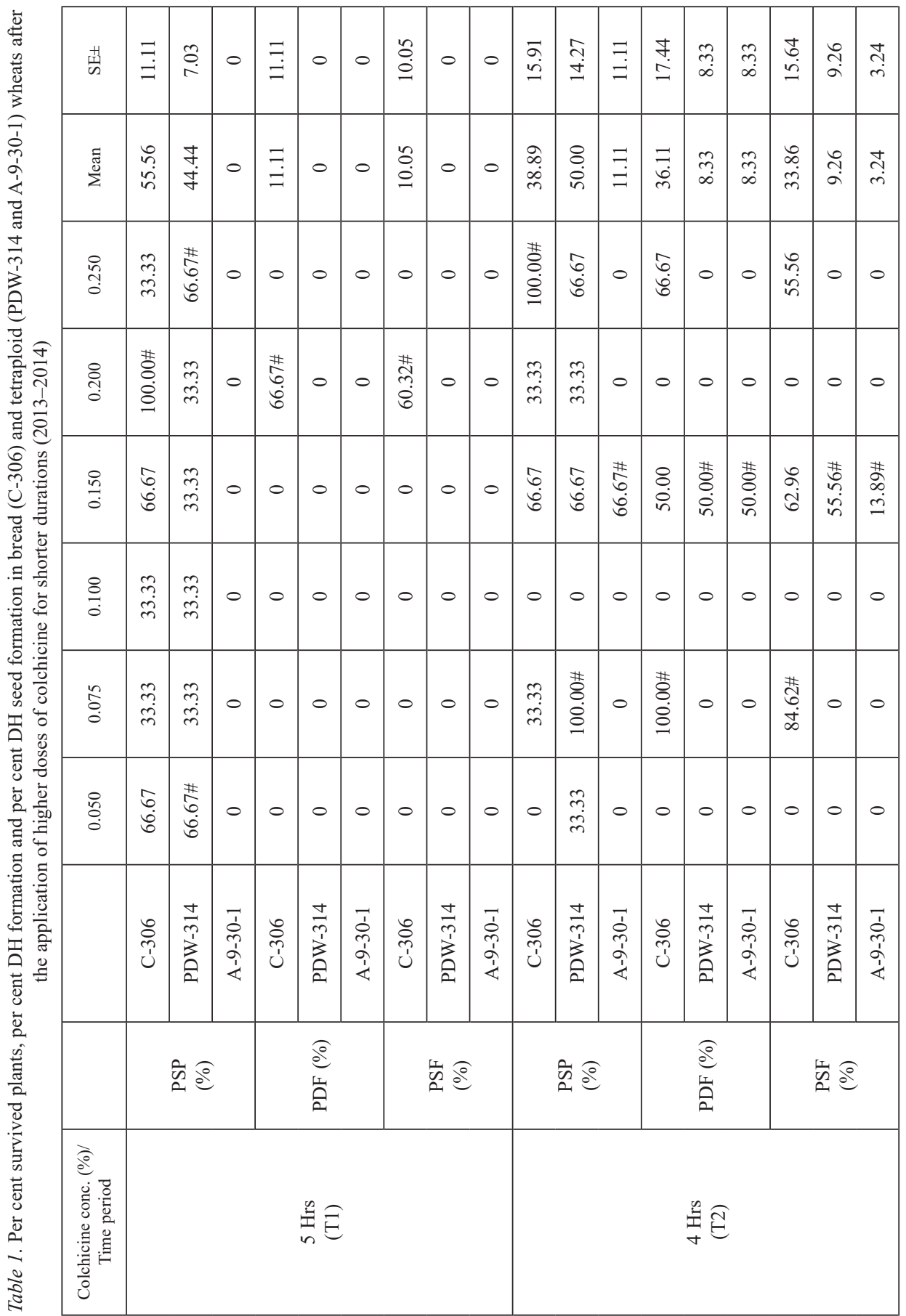




\begin{tabular}{|c|c|c|c|c|c|c|c|c|c|c|c|c|c|c|c|c|c|c|}
\hline 苾 & $\begin{array}{l}\bar{\sigma} \\
\stackrel{a}{a}\end{array}$ & $\begin{array}{l}\stackrel{\partial}{0} \\
\infty \\
\infty\end{array}$ & 0 & $\stackrel{\infty}{\stackrel{\infty}{\Xi}}$ & $\begin{array}{l}\exists \\
\Xi\end{array}$ & 0 & $\stackrel{\overbrace{}}{\Xi}$ & 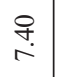 & 0 & $\begin{array}{l}\stackrel{\unlhd}{\Omega} \\
\stackrel{\Omega}{\sigma}\end{array}$ & $\stackrel{m}{r}$ & 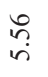 & $\begin{array}{l}\hat{6} \\
\dot{6} \\
\stackrel{0}{0}\end{array}$ & $\begin{array}{l}n \\
m \\
n\end{array}$ & $\begin{array}{l}\hat{6} \\
\stackrel{0}{0}\end{array}$ & $\tilde{n}$ & $\sqrt[n]{0}$ & $\stackrel{\sim}{\sim}$ \\
\hline$\stackrel{\text { हूँ }}{\Sigma}$ & $\begin{array}{l}\underset{Z}{i} \\
\mathbb{i}\end{array}$ & 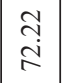 & 0 & $\begin{array}{l}8 \\
i \\
i\end{array}$ & $\begin{array}{l}\text { त̃ } \\
\text { त̇ }\end{array}$ & 0 & 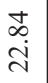 & $\stackrel{m}{\vec{n}}$ & 0 & $\stackrel{\infty}{\stackrel{\infty}{\sim}}$ & $\begin{array}{l}\text { Rे } \\
\text { nn } \\
\text { n. }\end{array}$ & $\begin{array}{l}\stackrel{\circ}{n} \\
i n\end{array}$ & $\begin{array}{l}\widehat{6} \\
\stackrel{0}{0}\end{array}$ & $\begin{array}{l}\hat{\sigma} \\
\dot{\gamma} \\
\dot{\gamma}\end{array}$ & $\begin{array}{l}\widehat{\sigma} \\
\underline{0}\end{array}$ & $\hat{n}$ & $\begin{array}{l}\overrightarrow{\mathrm{I}} \\
\mathrm{J}\end{array}$ & $\stackrel{\text { ஸे }}{\mathrm{i}}$ \\
\hline $\begin{array}{l}\text { î } \\
\text { त̂ } \\
0\end{array}$ & $\begin{array}{l}8 \\
\stackrel{8}{0}\end{array}$ & $\begin{array}{l}8 \\
\stackrel{8}{8}\end{array}$ & 0 & $\begin{array}{l}\text { 苦 } \\
\stackrel{0}{0} \\
\dot{0}\end{array}$ & 0 & 0 & $\begin{array}{l}\infty \\
\\
\sim \\
\sigma\end{array}$ & 0 & 0 & $\stackrel{m}{m}$ & $\begin{array}{l}\hat{6} \\
\dot{8}\end{array}$ & 0 & 0 & $\begin{array}{l}8 \\
\stackrel{8}{0} \\
\text { in }\end{array}$ & 0 & 0 & $\begin{array}{l}6 \\
6 \\
0\end{array}$ & 0 \\
\hline $\begin{array}{l}\text { ¿े } \\
\text { ஸุ }\end{array}$ & $\begin{array}{l}\widehat{6} \\
\text { ర్ర }\end{array}$ & $\begin{array}{l}8 \\
\stackrel{8}{8}\end{array}$ & 0 & $\begin{array}{l}8 \\
\stackrel{.}{0} \\
\text { in }\end{array}$ & $\begin{array}{l}\text { 苦 } \\
\dot{0} \\
\dot{0}\end{array}$ & 0 & $\stackrel{\infty}{\stackrel{\infty}{\sim}}$ & 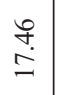 & 0 & 0 & $\begin{array}{l}\hat{6} \\
\dot{8}\end{array}$ & $\begin{array}{l}\text { 惡 } \\
\text { m} \\
\text { mे }\end{array}$ & 0 & $\begin{array}{l}8 \\
\stackrel{.}{0} \\
\text { in }\end{array}$ & $\begin{array}{l}\text { 营 } \\
\text { \& }\end{array}$ & 0 & $\begin{array}{l}\hat{6} \\
\dot{6} \\
\stackrel{0}{0}\end{array}$ & $\begin{array}{l}\text { 寺 } \\
\stackrel{\text {. }}{\text {. }}\end{array}$ \\
\hline 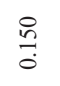 & $\begin{array}{l}\stackrel{8}{\circ} \\
\stackrel{8}{0}\end{array}$ & $\begin{array}{l}8 \\
\stackrel{8}{0}\end{array}$ & 0 & 0 & $\stackrel{m}{m}$ & 0 & 0 & $\begin{array}{l}\text { 营 } \\
\dot{+}\end{array}$ & 0 & 0 & $\begin{array}{l}\widehat{6} \\
\dot{8} \\
0\end{array}$ & 0 & 0 & $\begin{array}{l}8 \\
\stackrel{0}{0} \\
\text { in }\end{array}$ & 0 & 0 & $\underset{\text { bे }}{\text {. }}$ & 0 \\
\hline$\stackrel{8}{\stackrel{\circ}{0}}$ & $\begin{array}{l}\hat{6} \\
\text { రి. }\end{array}$ & $\stackrel{m}{m}$ & 0 & 0 & 0 & 0 & 0 & 0 & 0 & $\begin{array}{l}m \\
m \\
m\end{array}$ & $\begin{array}{c}m \\
m \\
m\end{array}$ & 0 & 0 & 0 & 0 & 0 & 0 & 0 \\
\hline \begin{tabular}{l}
$n$ \\
\multirow{0}{0}{} \\
0
\end{tabular} & $\begin{array}{l}8 \\
\stackrel{8}{0}\end{array}$ & $\begin{array}{l}8 \\
\stackrel{8}{0}\end{array}$ & 0 & $\stackrel{m}{m}$ & $\stackrel{m}{m}$ & 0 & $\begin{array}{l}\text { 茨 } \\
\dot{0} \\
\dot{0}\end{array}$ & $\begin{array}{l}m \\
m \\
m\end{array}$ & 0 & $\begin{array}{l}\frac{\#}{i} \\
\stackrel{0}{0} \\
\dot{0}\end{array}$ & $\begin{array}{l}\hat{6} \\
\dot{8}\end{array}$ & 0 & $\begin{array}{l}\text { 荅 } \\
\stackrel{8}{0}\end{array}$ & $\begin{array}{l}\text { 苦 } \\
\text { ¿े } \\
\text { ठ }\end{array}$ & 0 & $\begin{array}{l}\text { 㭙 } \\
\text { 吕 }\end{array}$ & 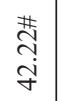 & 0 \\
\hline 号 & 0 & 0 & 0 & 0 & 0 & 0 & 0 & 0 & 0 & $\stackrel{m}{m}$ & $\stackrel{m}{m}$ & 0 & 0 & 0 & 0 & 0 & 0 & 0 \\
\hline & $\begin{array}{l}\text { ठ } \\
\text { ú } \\
\text { ú }\end{array}$ & 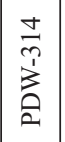 & 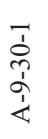 & ঠ̊ & 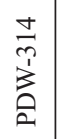 & 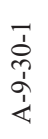 & $\begin{array}{l}\stackrel{8}{ల} \\
\text { Ú }\end{array}$ & 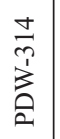 & $\begin{array}{l}\vec{j} \\
\dot{1} \\
\hat{1} \\
\dot{i}\end{array}$ & $\begin{array}{l}\stackrel{8}{0} \\
\text { Ú }\end{array}$ & 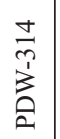 & 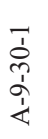 & $\begin{array}{l}\stackrel{8}{0} \\
\text { Ú }\end{array}$ & 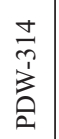 & 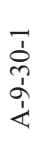 & $\begin{array}{l}\stackrel{8}{0} \\
\text { Uి }\end{array}$ & 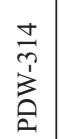 & 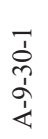 \\
\hline & & के & & & $\frac{2}{e^{o}}$ & & & $\frac{1}{\omega} e^{o}$ & & & है & & & $\begin{array}{l}\stackrel{0}{0} \\
\stackrel{1}{2}\end{array}$ & & & 忽 & \\
\hline 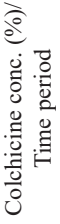 & & & & & $\stackrel{n}{\underline{\theta}} \widehat{\hat{\theta}}$ & & & & & & & & & 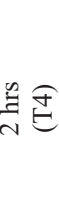 & & & & \\
\hline
\end{tabular}




\begin{tabular}{|c|c|c|c|c|c|c|c|c|c|c|c|c|c|c|c|c|c|c|}
\hline 䓀 & $\begin{array}{l}\vec{b} \\
\infty\end{array}$ & $\stackrel{n}{\circ}$ & $\stackrel{n}{\stackrel{n}{r}}$ & $\stackrel{\infty}{\stackrel{\infty}{\sim}}$ & $\begin{array}{l}\hat{\sigma} \\
0\end{array}$ & $\hat{\sigma}$ & $\stackrel{\text { nิ }}{=}$ & $\underset{\infty}{\stackrel{0}{\infty}}$ & $\stackrel{\infty}{\stackrel{\infty}{i}}$ & $\stackrel{0}{r}$ & 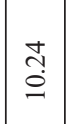 & $\stackrel{\text { mे }}{=}$ & 華 & $\underset{⿱}{\stackrel{J}{\Xi}}$ & $\hat{\sigma}$ & $\underset{\infty}{\stackrel{P}{\infty}}$ & $\stackrel{\widehat{N}}{=}$ & $\stackrel{\Xi}{\rightleftharpoons}$ \\
\hline 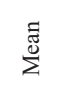 & $\stackrel{m}{m}$ & $\begin{array}{l}\stackrel{J}{*} \\
\dot{7}\end{array}$ & 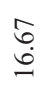 & $\stackrel{m}{m}$ & $\begin{array}{l}\hat{\sigma} \\
\underline{0}\end{array}$ & $\begin{array}{l}\hat{\sigma} \\
\underline{0}\end{array}$ & $\begin{array}{l}\text { ते } \\
\infty \\
\infty\end{array}$ & $\stackrel{\circ}{\infty}$ & $\stackrel{\infty}{\stackrel{\infty}{i}}$ & $\begin{array}{l}0 \\
n \\
i n\end{array}$ & $\exists$ & $\begin{array}{l}\hat{6} \\
.\end{array}$ & 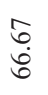 & $\begin{array}{l}= \\
\overrightarrow{0}\end{array}$ & $\begin{array}{l}\hat{6} \\
.\end{array}$ & $\begin{array}{l}0 \\
\stackrel{1}{8} \\
\text { in }\end{array}$ & $\begin{array}{l}\hat{a} \\
\dot{d}\end{array}$ & $\stackrel{F}{F}$ \\
\hline $\begin{array}{l}\text { ते } \\
\text { ஸे }\end{array}$ & $\stackrel{m}{m}$ & $\begin{array}{l}\frac{\#}{6} \\
6 \\
0 \\
0\end{array}$ & $\begin{array}{l}\text { 惡 } \\
\text { m} \\
\stackrel{m}{m}\end{array}$ & 0 & 0 & $\begin{array}{l}\text { 荅 } \\
\dot{8} \\
\dot{8}\end{array}$ & 0 & 0 & $\begin{array}{l}\text { 芳 } \\
\stackrel{ \pm}{ \pm}\end{array}$ & $\begin{array}{l}50 \\
8 \\
0\end{array}$ & $\stackrel{m}{m}$ & 0 & $\begin{array}{l}8 \\
\text { in }\end{array}$ & 0 & 0 & $\begin{array}{l}\mathscr{\infty} \\
\stackrel{+}{+}\end{array}$ & 0 & 0 \\
\hline ֻั & $\begin{array}{l}\frac{\#}{6} \\
\dot{0} \\
\dot{0}\end{array}$ & $\begin{array}{l}\frac{\#}{1} \\
6 \\
0 \\
0\end{array}$ & 0 & $\begin{array}{l}\text { 菅 } \\
\dot{8} \\
\dot{8}\end{array}$ & 0 & 0 & 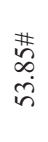 & 0 & 0 & $\stackrel{m}{m}$ & $\begin{array}{l}\hat{6} \\
8 \\
8\end{array}$ & 0 & 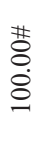 & $\begin{array}{l}8 \\
\text { in }\end{array}$ & 0 & $\begin{array}{l}\text { J̦ } \\
\infty \\
\infty \\
m\end{array}$ & $\stackrel{\infty}{\stackrel{\infty}{+}}$ & 0 \\
\hline$\stackrel{0}{\frac{1}{0}}$ & $\stackrel{m}{m}$ & $\stackrel{m}{m}$ & $\begin{array}{l}\text { 惡 } \\
m \\
m \\
m \\
m\end{array}$ & $\begin{array}{l}\text { 菅 } \\
\dot{8} \\
\stackrel{0}{0}\end{array}$ & $\begin{array}{l}\text { 苍 } \\
\text { ¿ } \\
\text {. }\end{array}$ & 0 & $\begin{array}{l}\text { \# } \\
\stackrel{0}{0} \\
\stackrel{0}{n}\end{array}$ & $\begin{array}{l}\text { 苦 } \\
\text { n } \\
\infty \\
+\infty\end{array}$ & 0 & $\begin{array}{l}\hat{\sigma} \\
\text { ه }\end{array}$ & $\begin{array}{l}\hat{6} \\
8 \\
0\end{array}$ & $\begin{array}{l}\text { 惡 } \\
\text { mे } \\
\text { mे }\end{array}$ & $\begin{array}{l}8 \\
\stackrel{\circ}{\circ}\end{array}$ & $\begin{array}{l}\text { 芳 } \\
\dot{8} \\
\stackrel{8}{-}\end{array}$ & $\begin{array}{l}\text { 容 } \\
\stackrel{+}{\circ} \\
\text {. }\end{array}$ & $\begin{array}{l}\hat{\sigma} \\
8 \\
0\end{array}$ & $\begin{array}{l}\text { 惡 } \\
\infty \\
\dot{\sim} \\
\dot{n}\end{array}$ & $\begin{array}{l}\text { 苂 } \\
\text { ○े } \\
\text { ते }\end{array}$ \\
\hline$\stackrel{8}{\stackrel{8}{\circ}}$ & 0 & $\underset{m}{m}$ & 0 & 0 & 0 & 0 & 0 & 0 & 0 & $\begin{array}{l}m \\
m \\
m\end{array}$ & $\stackrel{m}{m}$ & 0 & 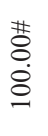 & 0 & 0 & $\begin{array}{l}\hat{\sigma} \\
\dot{\gamma}\end{array}$ & 0 & 0 \\
\hline $\begin{array}{l}n \\
\vdots \\
0 \\
0\end{array}$ & $\stackrel{m}{m}$ & $\stackrel{m}{m}$ & $\begin{array}{l}\text { 惡 } \\
m \\
m \\
m \\
m\end{array}$ & 0 & 0 & 0 & 0 & 0 & 0 & $\begin{array}{l}\hat{0} \\
\dot{8}\end{array}$ & $\begin{array}{l}\text { 苍 } \\
\dot{8} \\
\stackrel{8}{0}\end{array}$ & 0 & \&: & $\begin{array}{l}\hat{6} \\
\dot{0}\end{array}$ & 0 & $\begin{array}{l}\text { \# } \\
\infty \\
i \\
\infty\end{array}$ & 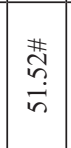 & 0 \\
\hline $\begin{array}{l}0 \\
\stackrel{0}{0} \\
0 \\
0\end{array}$ & $\stackrel{m}{m}$ & $\stackrel{m}{m}$ & 0 & 0 & 0 & 0 & 0 & 0 & 0 & $\begin{array}{l}6 \\
8 \\
8\end{array}$ & $\begin{array}{l}\hat{0} \\
0\end{array}$ & $\begin{array}{l}\text { 苦 } \\
\dot{0} \\
0\end{array}$ & $\begin{array}{l}8 \\
\text { in }\end{array}$ & 0 & 0 & $\stackrel{m}{\stackrel{\sim}{d}}$ & 0 & 0 \\
\hline & ঠூ & $\begin{array}{l}\frac{ \pm}{m} \\
\sum_{0}^{1}\end{array}$ & $\begin{array}{l}\overrightarrow{1} \\
\text { on } \\
\text { ó } \\
\dot{\alpha}\end{array}$ & ঠి & $\frac{ \pm}{3}$ & $\begin{array}{l}\overline{1} \\
\text { on } \\
o \\
\dot{\alpha}\end{array}$ & ס̊ & 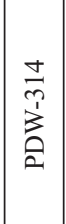 & $\begin{array}{l}\overline{1} \\
\text { d } \\
\text { ó } \\
\dot{\alpha}\end{array}$ & $\begin{array}{l}\text { o } \\
\text { un }\end{array}$ & $\begin{array}{l}\frac{\Delta}{m} \\
\text { 竞 } \\
\text { 至 }\end{array}$ & $\begin{array}{l}\overline{1} \\
\text { ô } \\
\text { ó } \\
\dot{j}\end{array}$ & 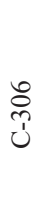 & 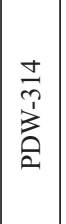 & $\begin{array}{l}\overline{1} \\
\text { d } \\
\hat{1} \\
\dot{\alpha}\end{array}$ & రొ & 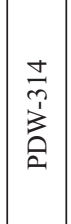 & $\begin{array}{l}\overline{1} \\
\text { ô } \\
\text { ó } \\
\dot{\alpha}\end{array}$ \\
\hline & & $\bar{\omega} \delta$ & & & $\frac{0^{\circ}}{2}$ & & & $\sqrt[w]{2} d$ & & & है & & & $\frac{\partial}{\partial}$ & & & $\stackrel{\omega}{2} \overbrace{}^{\varrho}$ & \\
\hline 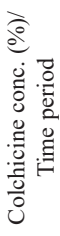 & & & & & $\begin{array}{l}\stackrel{n}{=} \\
i n\end{array}$ & & & & & & & & & $\begin{array}{l}\stackrel{n}{\oplus} \widehat{E} \\
\sigma\end{array}$ & & & & \\
\hline
\end{tabular}




\begin{tabular}{|c|c|c|c|c|c|c|c|c|c|c|c|c|c|c|c|c|c|c|}
\hline 䒰 & $\stackrel{\text { }}{=}$ & $\stackrel{\underline{\Xi}}{\underline{\Xi}}$ & $\stackrel{\text { mे }}{=}$ & $\begin{array}{l}\stackrel{+}{n} \\
\stackrel{0}{0}\end{array}$ & 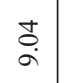 & $\underset{\infty}{m}$ & 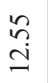 & $\begin{array}{l}\hat{\mathbf{c}} \\
\dot{\mathrm{j}}\end{array}$ & $\begin{array}{l}\text { gे } \\
\dot{+}\end{array}$ & $\stackrel{m}{r}$ & $\stackrel{\text { ले }}{=}$ & 0 & 0 & $\overbrace{\infty}^{m}$ & 0 & 0 & 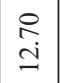 & 0 \\
\hline$\stackrel{\text { ⿷匚ँ }}{\stackrel{\Xi}{\Sigma}^{2}}$ & $\begin{array}{l}8 \\
\text { in }\end{array}$ & $\begin{array}{l}\hat{b} \\
\dot{8}\end{array}$ & $\begin{array}{l}\hat{\sigma} \\
\stackrel{0}{0}\end{array}$ & $\begin{array}{l}\hat{b} \\
\stackrel{0}{0}\end{array}$ & $\begin{array}{l}\infty \\
\dot{\emptyset} \\
\ddot{\eta}\end{array}$ & $\underset{\infty}{m}$ & $\begin{array}{l}\underset{2}{\stackrel{0}{0}} \\
\stackrel{\infty}{\infty}\end{array}$ & 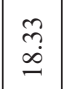 & $\begin{array}{l}\stackrel{g}{0} \\
\stackrel{+}{*}\end{array}$ & $\begin{array}{l}\text { J } \\
\text { J }\end{array}$ & in & 0 & 0 & $\overbrace{\infty}^{m}$ & 0 & 0 & 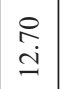 & 0 \\
\hline 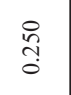 & $\begin{array}{l}\hat{6} \\
\stackrel{0}{0}\end{array}$ & $\begin{array}{l}\hat{0} \\
\dot{8}\end{array}$ & 0 & 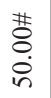 & 0 & 0 & $\begin{array}{l}\text { 哠 } \\
+ \\
\stackrel{0}{+}\end{array}$ & 0 & 0 & $\stackrel{m}{m}$ & $\begin{array}{l}\text { ⿵. } \\
\stackrel{8}{0}\end{array}$ & 0 & 0 & 0 & 0 & 0 & 0 & 0 \\
\hline $\begin{array}{l}\text { ণิ } \\
\text { ஸุ }\end{array}$ & $\begin{array}{l}\hat{6} \\
\stackrel{8}{0}\end{array}$ & $\begin{array}{l}\hat{0} \\
\stackrel{0}{0} \\
0\end{array}$ & $\begin{array}{l}\text { 葢 } \\
\ddot{0}\end{array}$ & 0 & $\begin{array}{l}\text { 茖 } \\
\text { : } \\
\text { in }\end{array}$ & $\begin{array}{l}\text { \# } \\
\text { o. } \\
\text { in }\end{array}$ & 0 & $\begin{array}{l}\text { 昔 } \\
\text { in } \\
\text { in }\end{array}$ & $\begin{array}{l}\text { 黛 } \\
\underset{\sim}{\infty} \\
\underset{\sim}{0}\end{array}$ & $\begin{array}{l}m \\
m \\
m\end{array}$ & $\begin{array}{l}50 \\
\stackrel{0}{0} \\
0\end{array}$ & 0 & 0 & $\begin{array}{l}\text { 营 } \\
\stackrel{\dot{0}}{\text { in }}\end{array}$ & 0 & 0 & $\begin{array}{l}\frac{H}{2} \\
\stackrel{2}{\circ}\end{array}$ & 0 \\
\hline$\frac{i}{0}$ & $\begin{array}{l}\hat{\circ} \\
\stackrel{0}{0}\end{array}$ & $\begin{array}{l}\text { \# } \\
\text { ○े } \\
\dot{8}\end{array}$ & 0 & 0 & 0 & 0 & 0 & 0 & 0 & $\begin{array}{c}\stackrel{m}{m} \\
\stackrel{m}{m}\end{array}$ & 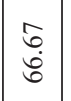 & 0 & 0 & 0 & 0 & 0 & 0 & 0 \\
\hline$\stackrel{8}{\circ}$ & $\stackrel{m}{m}$ & $\stackrel{m}{m}$ & 0 & 0 & 0 & 0 & 0 & 0 & 0 & $\stackrel{m}{m}$ & $\stackrel{m}{m}$ & 0 & 0 & 0 & 0 & 0 & 0 & 0 \\
\hline 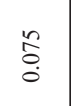 & $\begin{array}{l}\hat{6} \\
\stackrel{8}{0}\end{array}$ & $\begin{array}{l}\text { 荅 } \\
\stackrel{8}{0}\end{array}$ & $\begin{array}{l}\text { 惡 } \\
\text { m } \\
\text { m }\end{array}$ & $\begin{array}{l}\text { 茖 } \\
\text { ¿ } \\
\text { in }\end{array}$ & 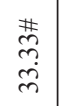 & 0 & $\begin{array}{l}\text { 荅 } \\
\stackrel{i}{i}\end{array}$ & $\begin{array}{l}8 \\
\dot{i} \\
\text { m }\end{array}$ & 0 & $\begin{array}{l}\text { 苦 } \\
\stackrel{0}{0} \\
\text { : }\end{array}$ & $\begin{array}{l}\hat{6} \\
\dot{0}\end{array}$ & 0 & 0 & 0 & 0 & 0 & 0 & 0 \\
\hline 号 & 0 & $\stackrel{m}{m}$ & 0 & 0 & 0 & 0 & 0 & 0 & 0 & $\begin{array}{l}\text { 苦 } \\
\stackrel{0}{0} \\
\stackrel{0}{0}\end{array}$ & 0 & 0 & 0 & 0 & 0 & 0 & 0 & 0 \\
\hline & $\begin{array}{l}\stackrel{8}{0} \\
\text { Ú }\end{array}$ & 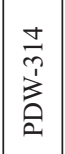 & $\begin{array}{l}\overline{1} \\
\text { on } \\
\text { ó } \\
\dot{\alpha}\end{array}$ & $\begin{array}{l}\stackrel{ల}{1} \\
\text { Ú }\end{array}$ & 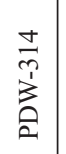 & 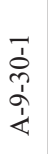 & $\begin{array}{l}\stackrel{8}{0} \\
\text { Uే }\end{array}$ & 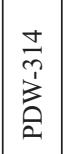 & 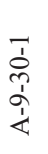 & $\begin{array}{l}\stackrel{8}{0} \\
\text { ú }\end{array}$ & 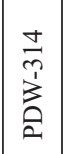 & 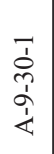 & 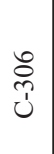 & $\begin{array}{l} \pm \\
\vec{m} \\
\sum_{0}^{1} \\
\vec{a}\end{array}$ & 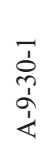 & $\begin{array}{l}\text { ठ̊ } \\
\text { Uు }\end{array}$ & $\begin{array}{l}\frac{\Delta}{m} \\
\sum_{0}^{1}\end{array}$ & $\begin{array}{l}\overline{1} \\
\text { ô } \\
\text { á } \\
\text { ¿ }\end{array}$ \\
\hline & & है & & & $\frac{\widehat{o}}{\stackrel{c}{c}}$ & & & 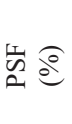 & & & $\ddot{\tilde{\omega}} \precsim$ & & & $\frac{\widehat{d}}{\stackrel{1}{a}}$ & & & w & \\
\hline 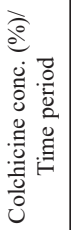 & & & & & 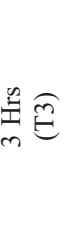 & & & & & & & & & 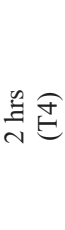 & & & & \\
\hline
\end{tabular}


study found colchicine concentration of $0.075 \%$ for $4 \mathrm{hrs}$ in bread wheat and $0.15 \%$ for 4 hrs in durum wheat to be effective, efficient and economically viable doses for doubling of chromosomes.

\section{Discussion}

Wide hybridization is the most commonly used conventional approach in crop improvement for intervarietal or interspecific hybridization and it takes 6 to 7 years to achieve homozygosity. The $\mathrm{DH}$ breeding is an alternative to the conventional breeding approaches that has accelerated the crop improvement programmes by the achievement of absolute homozygosity in just 2 years (Baenziger et al. 2001; Garcia-llamas et al. 2004). The present study was executed with the goal to standardize the protocol for in vitro application of colchicine to haploid regenerants for efficient recovery of doubled haploids. In hexaploid wheat, DH-40, sufficient numbers of haploid plants were not formed for colchicine treatment and was found to be sensitive for various haploid induction parameters.

The hexaploid wheat, C-306 and tetraploid wheat, PDW-314, showed high survival rate at most of the colchicine concentration whereas, low survival rate of A-9-30-1 indicated the sensitivity of genotype to the application of colchicine. The per cent DH formation and the per cent DH seed formation was found to be higher at $0.075 \%$ for $4 \mathrm{hrs}$ followed by $0.15 \%$ for $4 \mathrm{hrs}$ and $0.20 \%$ for $5 \mathrm{hrs}$ in hexaploid wheat. In tetraploid wheat, colchicine doses of $0.20 \%$ for $2 \mathrm{hrs}$ and $0.15 \%$ for $4 \mathrm{hrs}$ in both PDW-314 and A-9-30-1 followed by $0.075 \%$ for $2 \mathrm{hrs}$ and $4 \mathrm{hrs}$ and $0.20 \%$ for $3 \mathrm{hrs}$ in PDW-314 were found to be effective. Therefore, colchicine concentration of $0.075 \%$ for $4 \mathrm{hrs}$ in bread wheat and $0.15 \%$ for $4 \mathrm{hrs}$ in durum wheat can be recommended as effective, efficient and economically viable dose for doubling of chromosomes due to high mortality rate at higher concentrations. The results agree with the study conducted by Hua et al. (2005) which revealed that a colchicine concentration of $750 \mathrm{mg} /$ litre $(0.075 \%)$ to haploid seedlings obtained through wheat (Triticum aestivum) $\times$ maize (Zea mays) was optimum. For durum wheat results are in concordance with Jauhar (2003) who proposed treatment of cytologically confirmed haploid plantlets (at the 2 - or 3 -leaf stage) with a $0.2 \%$ aqueous solution of colchicine. Higher doses of colchicine were found to be more effective as compared to the lower doses. The present findings with respect to ineffectiveness of lower doses below $0.05 \%$ are in concordance with existing reports which have not found chromosome doubling at lower doses, i.e. below $0.05 \%$. DH seed formations was observed at higher dose of $0.20 \%$ but due to higher mortality rate at this dose, the doses lower than this can be interpreted as the effective and economical viable for the doubling of chromosomes.

Therefore, the dose of colchicine for in vitro application recommended through the present experiment can enhance the efficiency of doubled haploid formation in hexaploid and tetraploid wheat and thus, result in accelerating the crop improvement programme through doubled haploidy breeding approach. 


\section{References}

Baenziger, P.S., Moonkim, K., Halilogue, K. 2001. Wheat in vitro breeding. In: Bonjean, A.P. and Angus, W.J. (eds). The world wheat book: A history of wheat breeding Lavoisier Publishers, Paris. pp. 979-1000.

Bains, N.S., Mangat, G.S., Singh, K., Nanda, G.S. 1998. A simple technique for the identification of embryo carrying seeds from wheat $\times$ maize crosses prior to dissection. Plant Breed. 117:191-192.

Barclay, I.R. 1975. High frequencies of haploid production in wheat (Triticum aestivum) by chromosome elimination. Nature (London) 256:410-411.

Chaudhary, H.K. 2008. Dynamics of wheat $\times$ Imperata cylindrica - a new chromosome elimination mediated system for efficient haploid induction in wheat. In: Appels, R., Eastwood, R., Lagudah, E., Langridge, P., Mackay, M., McIntyre, L., Sharp, P. (eds), Proc. $11^{\text {th }}$ Int. Wheat Genetics Symp. University of Sydney Press. Sydney, Australia. pp. 647-650.

Chaudhary, H.K. 2009. New frontiers in chromosome engineering: Genetic upgradation of bread wheat for varied agroclimatic situations in north-west Himalayas. In: Bandyopadhyay, A., Prasanna, B.M., Mohapatra, T., Talukdar, A., Tomar, S.M.S. (eds). Proc. National Seminar on Designing Crops for the Changing Climate. Ranchi, Jharkhand, India. pp. 51-52.

Chaudhary, H.K. 2010a. New frontiers in DH Breeding: Dynamics of wheat $\times$ Imperata cylindrica system of chromosome elimination-mediated approach of DH production for striking success in alien introgression endeavours in bread wheat. In: Proc. Eucarpia Cereal Section Meeting: Innovations in Cereal Breeding. Cambridge, UK. p. 73.

Chaudhary, H.K. 2010b. Chromosome elimination process - a boon or bane for alien introgression in wheat. In: Zhang, X., Jin, W., Hin, F. (eds). Proc. $4^{\text {th }}$ Asian Chromosome Colloquium. Beijing, China. p. 21.

Chaudhary, H.K., Sethi, G.S., Singh, S., Pratap, A., Sharma, S. 2005. Efficient haploid induction in wheat by using pollen of Imperata cylindrica. Plant Breeding 124:96-98.

Chaudhary, H.K., Singh, S., Sethi, G.S. 2002. Interactive influence of wheat and maize genotypes on haploid induction in winter $\times$ spring wheat hybrids. J. Genet. Breed. 56:259-266.

Chaudhary, H.K., Tayeng, T., Kaila, V., Rather, S.A. 2013a. Enhancing the efficiency of wide hybridization mediated chromosome engineering for high precision crop improvement with special reference to wheat $\times$ Imperata cylindrica system. The Nucleus 56:7-14.

Chaudhary, H.K., Tayeng, T., Kaila, V., Rather, S.A. 2013b. Use of asynchrony in flowering for easy and economical polyhaploid induction in wheat following Imperata cylindrica-mediated chromosome elimination approach. Plant Breeding 132:155-158.

Chauhan, H., Khurana, P. 2011. Use of doubled haploid technology for development of stable drought tolerant bread wheat (Triticum aestivum L.) transgenics. J. Plant Biotechnol. 9:408-417.

Chu, C.C., Wang, C.C., Sun, C.S., Chien, N.P., Yin, K.C., Hsu, C. 1973. Investigation on the induction and morphogenesis of wheat (Triticum aestivum) pollen plants. Acta Bot. Sin. 15:1-11.

Foster, E., Hawkins, A., Adamson, A. 2010. Young person's food atlas: pre-school. Food Standards Agency, London.

Garcia-llamas, C., Ramirez, M.C., Ballesteros, J. 2004. Effect of pollinator on haploid production in durum wheat crossed with maize and pearl millet. Plant Breeding 123:201-203.

Hua, C., Chuan, M.X., Zhong, L.W. 2005. Chromosome doubling in wheat haploids from inter-generic cross between wheat and maize. Journal of Triticeae Crops 25:20-22.

Jauhar, P.P. 2003. Haploid and doubled haploid production in durum wheat by wide hybridization. In: M. Maluszynski et al. (ed.) Doubled haploid production in crop plants: A manual, Kluwer Academic Publishers, Dordrecht, the Netherlands. pp. 161-167.

Kaila, V., Chaudhary, H.K., Tayeng, T., Rather, S.A. 2012. Resolution of genetic mechanism of chromosome elimination in wheat $\times$ Imperata cylindrica system of doubled haploidy breeding: the genome responsible. In: Proceedings of National Seminar on Plant Cytogenetics: New Approaches, Department of Botany, Punjabi University, Patiala, Punjab, India. p. 82.

Laurie, D.A., Bennett, M.D. 1986. Wheat × maize hybridization. Can. J. Genet. Cytol. 28:313-316.

Laurie, D.A., Bennett, M.D. 1987. Annual Report of the Plant Breeding Institute. 66-68. Wide crosses involving maize (Zea mays). 
Laurie, D.A., Bennett, M.D. 1988. The production of haploid wheat plants from wheat $Æ$ maize crosses. Theor. Appl. Genet. 76:393-397.

Mahato, A., Chaudhary, H.K. 2015. Relative efficiency of maize and Imperata cylindrica for haploid induction in Triticum durum following chromosome elimination-mediated approach of doubled haploidy breeding. Plant Breeding 134:379-383.

Murashige, T., Skoog, S. 1962. A revised medium for rapid growth and bioassays with tobacco tissue cultures. Physiol. Plants 15:473-497.

Ouyang, J., Hu, H., Chuang, C.C., Tseng, C.C. 1973. Induction of pollen plants from anthers of Triticum aestivum L. cultured in vitro. Sci. Sinica 16:79-95.

Patnaik, D., Khurana, P. 2001. Wheat biotechnology: a mini review. Electron. J. Biotechnol. 4:74-102.

Wang, Y.Y., Sun, C.S., Wang, C.C., Chien, N.F. 1973. The induction of pollen plantlets of triticale and Capsicum annum from anther culture. Sci. Sinica 16:147-151.

\section{Electronic Supplementary Material (ESM)}

Electronic Supplementary Material (ESM) associated with this article can be found at the website of CRC at http://www.akademiai.com/content/120427/

Electronic Supplementary Table S1. Parentage and source of bread wheat genotypes

Electronic Supplementary Table S2. Parentage and source of durum wheat genotypes

Electronic Supplementary Table S3. Plan for in vitro application of colchicine

Electronic Supplementary Table S4. Per cent survived plants, per cent DH formation and per cent seed formation in bread (C-306) and tetraploid (PDW-314 and A-9-30-1) wheats after the application of lower doses of colchicine for longer durations (2013-2014 and 2014-2015) 